\title{
Polonceau versus Ardant: efficiency versus aesthetics?
}

\author{
M. de Bouw ${ }^{1,2} \&$ I. Wouters ${ }^{3}$ \\ ${ }^{1}$ Artesis University College Antwerp, Department of Architectural \\ Sciences, Conservation of Monuments and Sites, Belgium \\ ${ }^{2}$ Belgian Building Research Institute, Lab of Renovation, Belgium \\ ${ }^{3}$ Vrije Universiteit Brussel, Department of Architectural Engineering, \\ Belgium
}

\begin{abstract}
In 1839 engineer Camille Polonceau invents the Polonceau truss. However, for a long time architects refuse to openly show iron structures in public buildings and constructions for aesthetical reasons. In spite of this, engineers acknowledged the ample structural opportunities of iron roofs, which urged them to experiment with curved trusses in order to avoid the industrial looking bar roof trusses. Nevertheless, today one knows the Polonceau truss, whereas few are familiar with its aesthetical counterpart: the Ardant truss.

This curved roof truss makes use of an inscribed arch, tangent and framed to the principal rafters of a gable roof, in order to rigidify the roof structure and avoid interfering tension ties. According to the spirit of age, this solution with its high decorative potential seemed to provide a satisfying answer to both the aesthetical as well as the structural problems of iron roof trusses in public edifices. Subsequently, it was applied many times in swimming pools, stock exchange buildings, schools, platform coverings, palaces, malls, etc.

In Belgium it was widely used to span the central covered courtyard of the Brussels model schools which were built between 1875 and 1920, and which were very innovative with regard to architecture, educational policy, hygiene, heating and ventilation techniques, safety, etc.

This paper deals with the debate on the efficiency and aesthetics of iron architecture in the $19^{\text {th }}$ and $20^{\text {th }}$ century, by means of a structural analysis of the iron Polonceau and Ardant roof trusses of the Brussels model schools. The paper
\end{abstract}


concludes with three decision schemes that can be used to assess Ardant trusses in general.

Keywords: Polonceau roof truss, Ardant roof truss, curved roof truss, structural analysis, structural iron, model school, Brussels, efficiency, aesthetics.

\section{Introduction}

The introduction of iron and steel in $19^{\text {th }}$ and $20^{\text {th }}$ century (non-industrial) architecture was not accepted without striking a blow. Some prominent figures such as the Belgian engineer Arthur Vierendeel (1852-1940) advanced the thesis that iron already came out of the shadow of stone and wood as a fully fledged building material at the mid- $19^{\text {th }}$ century, yet many of his contemporaries completely disagreed [1-4].

Nevertheless, due to cost reducing measures (possibility to create long spans, open plans, easy-to-assemble prefabricated components, etc.) these materials would rapidly be used on a large scale in industrial buildings. According to the prominent Belgian professor Paul Combaz (1845-1920), they even had become the basic material for industrial buildings by 1897 [5]. Yet, he immediately points out that from a structural and aesthetical point of view one cannot openly show these materials to the public, as the common people would judge them less stable and safe because of their extremely slender and filigree appearance [5].

It is beyond doubt that people were in two minds at that time about iron architecture. In Belgium, this new iron architecture and the contrast between efficiency and aesthetics found virtue in the Brussels model schools [6].

\section{The Brussels model schools and their roof construction}

The idea of the Brussels model schools was developed between 1860 and 1875 by the pedagogical pressure group Ligue de l'Enseignement, the mayor of Brussels Karel Buls and the Brussels architect Ernest Hendrickx [6]. In 1875, the first model school, viz. the École Modèle, was built [7, 8]. Because of the revolutionary ideas on hygiene facilities, intelligent heating and ventilation systems, pedagogical ideologies, etc. this school building became an icon, which was copied on large scale all over Belgium and abroad (e.g. France, Spain) [6, 9]. In sum, over 55 schools were built according to this layout in Brussels solely.

One of these schools' main characteristics is the presence of a central covered courtyard or so-called préau. To span this préau, several roof constructions were used (Figure 1). Analysis of the iron roof trusses of the model schools revealed hidden and visible trusses. It is striking that the hidden ones always consist of straight duo pitched industrial bar roof trusses, such as the German, English or Belgian type [6]. As these were not considered beautiful, they were concealed from sight by a false ceiling. On the other hand, just like one finds two imports of the Art Nouveau - viz. the geometrical and pure one (P. Hankar, H. Jacobs, P. Hamesse, etc.) versus the natural and organic trend (V. Horta, G. Strauven, E. Blérot, etc.) - one finds two similar imports with regard to the visible metal roof trusses: the plain and straightforward Polonceau truss versus the decorative and 


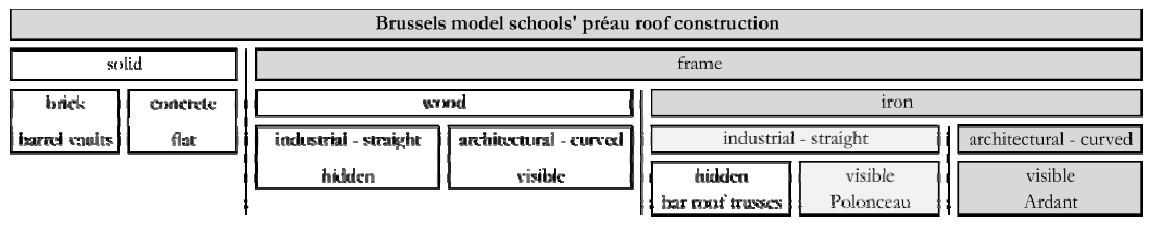

Figure 1: Possible roof constructions to span the Brussels model schools' préau.
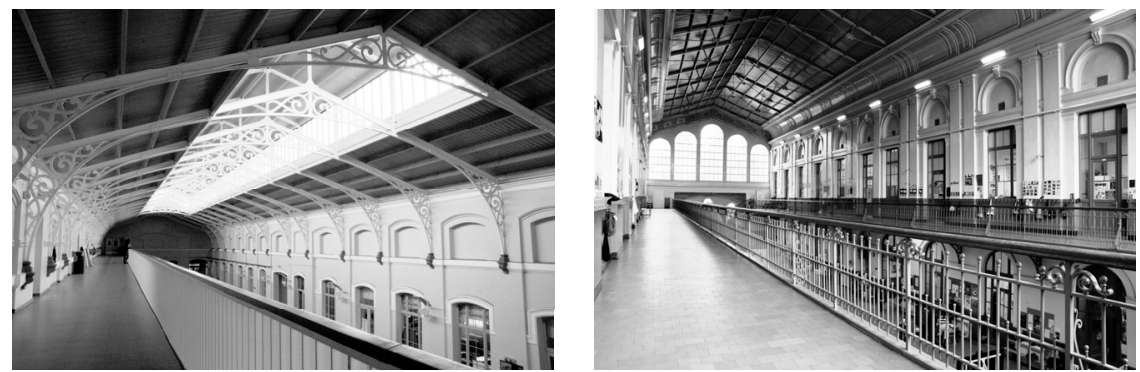

Figure 2: Ardant truss of the 1880 municipal school no.5\&6 "des Étangs" (left); Polonceau truss of the 1906 municipal school no.12 "Jardins d'Élise" (right).

smooth Ardant truss (Figure 2). In all, twenty-five Brussels model schools made use of visible iron roof trusses to cover their préau (Figure 4): fourteen used Ardant trusses, whereas eleven preferred Polonceau trusses.

\section{Polonceau versus Ardant: efficiency versus aesthetics?}

The Ardant and Polonceau trusses of the model schools reflect well the ongoing debate on the aesthetics and efficiency of iron architecture. Both truss types span the 9 to $15 \mathrm{~m}$ wide préau, yet the underlying idea was completely different.

\subsection{Origins and setup}

The Polonceau truss originated from the idea to use all of its components in an optimal way. In order to achieve this, the French engineer Camille Polonceau invented in 1839 a gable roof by means of two inclined trussed beams and a central tension tie [10-13]. This resulted in one of the first roof trusses to be simple, efficient and economic at the same time. After all, at that time, the cost of iron structures was merely determined by the amount of material, as labour costs were very low compared to material costs $[10,14,15]$. Together with the ease of calculation (by means of graphic statics), this resulted in a frequent use of this truss typology until the 1890's.

Nevertheless, because of its lack of architectural expression and industrial looks, some architects experimented with curved roof trusses [16]. One of the major initial downsides was the persistent necessity of tension ties to resist the 
lateral thrust forces induced by the curved form (Figure 3(a)). To resolve this problem, the French military engineer Paul-Joseph Ardant - a teacher at the École d'Application de l'Artillerie et du Génie at Metz - published his work "Études théoriques et expérimentales sur l'établissement des charpentes à grande portée" in 1840. This publication provided the results of his experiments on fourteen curved roof truss types $[16,17]$. He concluded that the arch is the most flexible truss form and that all arches exert (some) horizontal thrust on the walls, although theoretically the semi-circular one should not. In order to stiffen this form, he recommended the spandrel arch, which is tangent and framed to the principal rafters of a gable frame (Figure 3(b)). This precursor of the de Dion truss (Figure 3(c)) and the three-hinged arch (Figure 3(d)), which were used for the first time at the Paris Universal Expositions respectively in 1878 and 1898, is called an Ardant truss in the present paper. In time, Ardant's setup would become very popular for prestigious public edifices such as railway stations, covered marketplaces, department stores and school buildings [6].

(a)

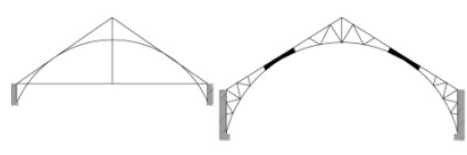

(c) (d)

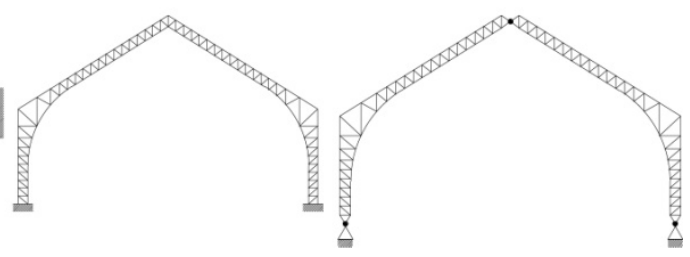

Figure 3: Schematic evolution of the arched roof truss and its bearings from the tied arch (a) to the untied Ardant truss (b) and de Dion truss (c), finally resulting in the large-scale three-hinged arch (d).

\subsection{The duality within the model schools}

As the cost of iron structures at that time was merely determined by the amount of iron or steel, engineers focussed on the weight-to-span ratio to determine whether a structure was efficient/economic or not. That is why C. Polonceau states in his 1839 publication in the French journal "Revue Générale de l'Architecture et des Travaux Publics" that the necessary amount of material in his configuration was very limited, resulting in a very light and thus cheap truss $[10,18]$.

According to this definition, it seems that the earliest Ardant trusses could keep pace with the Polonceau trusses (e.g. values of the weight-to-span ratio of 0.31 and $0.39 \mathrm{kN} / \mathrm{m}$ for the two earliest Ardant trusses, compared to a more or less steady ratio of $0.33 \mathrm{kN} / \mathrm{m}$ for the model schools' Polonceau trusses) (Table 1). Taking into account the distance between two parallel trusses (to relate the truss' self-weight to the supported area), this trend is confirmed: the Polonceau's weight-to-surface ratio being constant and around $0.08 \mathrm{kN} / \mathrm{m}^{2}$, and the one of the two earliest Ardant trusses being 0.10 and $0.11 \mathrm{kN} / \mathrm{m}^{2}$. These results would make the Ardant truss a very efficient and a decorative truss at the same time, which would make it a perfect substitute for the Polonceau truss. 
Table 1: Comparison of the Ardant and Polonceau trusses' efficiency according to the $19^{\text {th }}$ century interpretation.

\begin{tabular}{|c|c|c|c|c|c|c|c|}
\hline & Date & School & $\begin{array}{c}\text { Self- } \\
\text { weight } \\
{[k N]}\end{array}$ & $\begin{array}{c}\text { Span } \\
{[\mathrm{m}]}\end{array}$ & $\begin{array}{c}\text { Max. truss } \\
\text { distance } \\
\text { [m] }\end{array}$ & $\begin{array}{l}\text { Weight-to- } \\
\text { span ratio } \\
{[\mathrm{kN} / \mathrm{m}]}\end{array}$ & $\begin{array}{l}\text { Weight-to- } \\
\text { surface ratio } \\
{\left[\mathbf{k N} / \mathbf{m}^{\mathbf{2}]}\right.}\end{array}$ \\
\hline \multirow{7}{*}{$\begin{array}{l}\lambda \\
\mathrm{r} \\
\mathrm{d} \\
\mathrm{a} \\
\mathrm{n} \\
\mathrm{t}\end{array}$} & $1878-80$ & School no.13 "Cooremans" & 2.93 & 9.31 & 3 & 0.31 & 0.10 \\
\hline & $1880-3$ & School no. .5 and 6 "des Étangs" & 5.12 & 13 & 3.45 & 0.39 & 0.11 \\
\hline & $1891-2$ & School no.6"J.J. Michcl" & 14.44 & 14.6 & 4.3 & 0.99 & 0.23 \\
\hline & 1896.7 & Sch(r)l no, 7 "Batcon Steens" & 16.86 & 15 & 4.5 & 1.12 & 0.25 \\
\hline & 1902 & School P6/13 "I Les Marronniers" & 10.33 & 11.5 & 4.8 & 0.90 & 0.19 \\
\hline & $1902-6$ & School no.10 “Karcl Buls” & 15.55 & 15 & 3.75 & $1 .(14$ & 0.28 \\
\hline & $1910-4$ & Schøol "Dachsbeck" & 9.99 & 12.4 & 3.7 & 0.81 & 0.22 \\
\hline \multicolumn{3}{|c|}{ 1875-1920 - Irerige - Poloncrunt } & $\$ .19$ & 12.9 & 4.3 & 0.33 & 0.08 \\
\hline
\end{tabular}

Nevertheless, these findings raise some questions. First of all, a Polonceau truss uses each material and component in (almost) optimal conditions (compression/tension only), whereas the Ardant truss does not. So, how can they be equally efficient? Secondly, it can be noticed that even though the span shows no significant change over time, the self-weight of the Ardant trusses does (Table 1): from 1890 onwards the self-weight all of a sudden raises strongly, resulting in a weight-to-span ratio between 0.81 and $1.12 \mathrm{kN} / \mathrm{m}$ (weight-to surface ratio between 0.19 to $0.28 \mathrm{kN} / \mathrm{m}^{2}$ ), which is in striking contrast with the ratio of the earliest examples and the fact that the Polonceau's ratio stayed constant during the same period. So, how comes that the more recent Ardant trusses seem to be engineered in a less efficient way? After all, engineers always search(ed) to improve the efficiency. And at last, bearing this last question in mind, how comes that one can notice a shift from the Polonceau truss towards the apparently less efficient Ardant truss to span the schools' préau from 1900 onwards (Figure 4)?

\subsection{Historic motives}

In order to formulate an answer to these questions and ambiguities, one needs to focus on continuous interplay between the aesthetics, the evolution of the calculation methods and the aim for standardization.

As the industrial bar roof trusses were not esteemed beautiful, all of these were hidden behind a false ceiling in the model schools, except for the Polonceau roof truss. Although this truss was also criticized because of its industrial looks and the loss of free space due to the multitude of triangulated members $[15,18]$, it was often applied because of its efficiency and ease of calculation. Still, the curved form always appealed to the architects' and engineers' imagination and many experiments were performed [19]. However, whereas during the time of the model schools the Polonceau trusses could already be calculated accurately using the graphic statics, this was not the case for the Ardant trusses. So, because of a suitable alternative, architects and engineers embellished this truss and imitated the curved form they strove for by applying richly decorated spandrels at the side springings, which seemed to be a typical solution for prestigious edifices (Figure 5, left). 

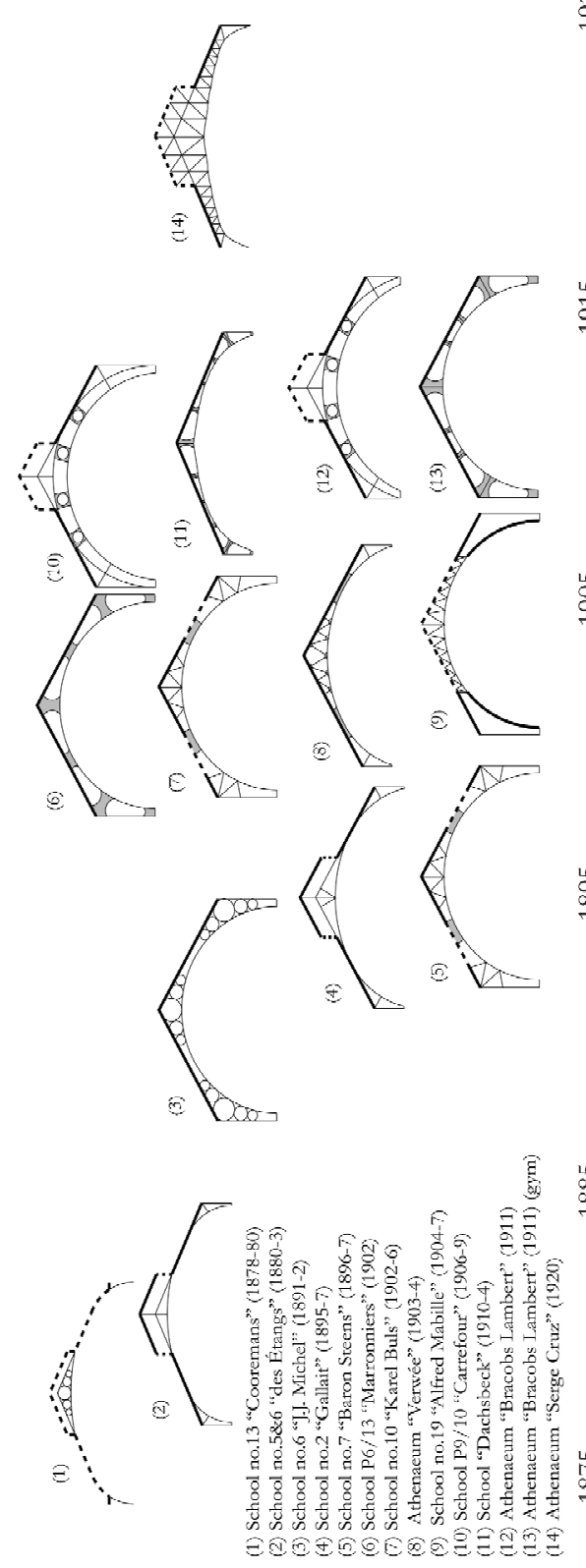

$\stackrel{2}{a}$
$\stackrel{2}{ }$
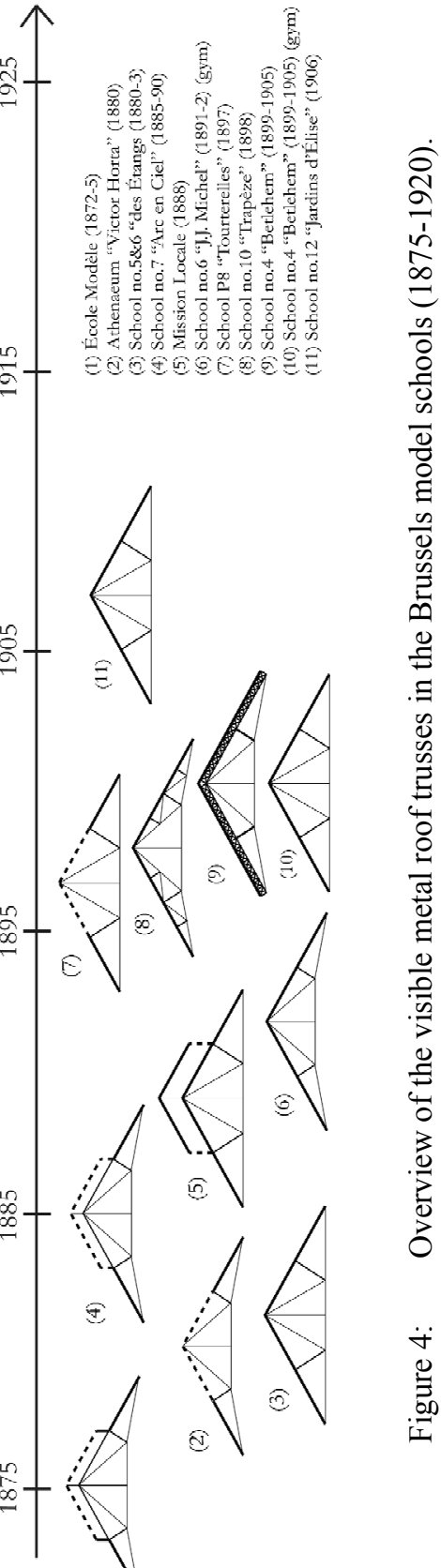

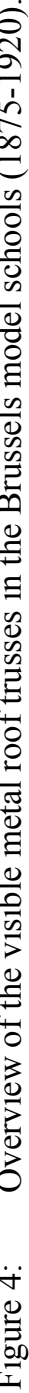



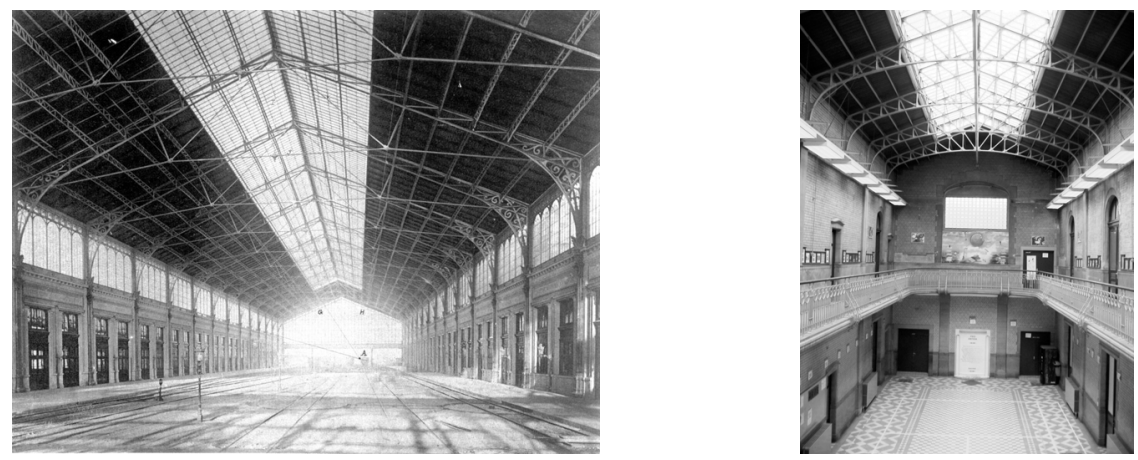

Figure 5: The Budapest main railway station (1877) (left) [15]; industriallooking bar-trussed Ardant truss of the Brussels Athenaeum Serge Cruz (1920) (right).

Engineer Arthur Vierendeel proved in his 1902 publication that there was no decent alternative by criticizing the earliest iron "Ardant trusses" because their engineers did not consider nor use the implicit interaction between the principal rafter and the tangential arch [15]. Though, according to him, a well-designed and well-calculated Ardant truss which did use this interaction was, for instance, up to $40 \%$ more efficient than a de Dion truss. That is why he presented in that same publication for the first time in Belgium a suitable calculation method that took the (curved) web members into account to dimension the truss [15]. As a consequence, prior to 1900 most of the architects of the model schools recurred to the Polonceau truss. Yet, once Vierendeel published his calculation technique, the model schools' engineers and architects clearly opted for 'genuine' curved Ardant trusses (Figure 4).

Finally, a third argument would be the raise of standardisation. After 1900, steel production went flat out. The production costs and prizes dropped, and forgeries started to make catalogues with standard sections. As a result the costs of a structure would mainly be determined by the amount of labour instead of material. This entailed that the production of special pieces (e.g. to fit all components of the Polonceau trusses together) all of a sudden became a major disadvantage [18]. Moreover, this evolution favoured the Ardant truss as it made use of standard section irons, simple plates and flat irons only.

\subsection{Present-day structural comparative analysis}

At the time of the model schools no compulsory calculation methods and design rules existed. Merely a restricted number of vague and divergent guidelines were in circulation, but mostly the design was determined by (the experience of) the designer himself. Within the model schools, literature search and study of the records did not reveal any original calculation notes. As a consequence, no historic design values are known for these trusses. Moreover, as previously mentioned, an important difference in efficiency (according to the historic definition) could be noticed between the earliest and the later Ardant trusses. In 
order to establish whether or not these findings affected the trusses' structural behaviour and to what extent, the Eurocodes of today's practice were used to settle on their thrust and reaction forces, member stresses, deflections and deformations, and strength and stability [6].

According to the historic definition of efficiency, the first two Ardant trusses equal the Polonceau's efficiency notwithstanding less optimal use of components (bending) (Table 1). Present-day analyses, however, indicated severe instability risks for these trusses. Recent visual inspections did not reveal any stability problems yet. Nonetheless, the extreme results of the calculations clearly urge to perform further in-depth investigations.

The results of the stress analyses, section checks and the deflections of the later Ardant trusses were satisfying, and did not reveal a significant difference between the Ardant and the Polonceau trusses. With regard to the thrust forces, all of the Ardant trusses do indeed exert thrust forces as stated by P.-J. Ardant himself (3.1 - Origins and setup, p.3). A remarkable fact, however, was that - in contrast to what is generally believed - all of the model schools' Polonceau trusses do also exert thrust forces on their bearings as a result of their execution on-site with fixed ends. The structural analysis also demonstrated that both truss types' thrust forces are the same magnitude. The stability checks established an inferior structural behaviour of the Ardant trusses, yet a positive evolution could be detected [6].

\section{Decision charts}

To make detailed assessments and draw proper conclusions, every case that needs to be judged, needs to be examined separately. Still, to guide engineers, architects, historians, etc. in their preparatory assessment of Ardant trusses, the results of the analyses of the model schools' Ardant trusses were converted into easy-to-use decision schemes [6]. In the next paragraphs three of them will be illustrated by applying them to the 1904-7 "Alfred Mabille" model school.

Figure 1 shows the standard options that were used to span the roof of the Brussels model schools. Whereas the table indicates that straight industrial bar roof trusses always were hidden in the case of the model schools, the curved bar roof truss of the Mabille school literally makes the transition between the typical hidden straight industrial bar roof truss and the visible curved Ardant bar truss: the side parts are still hidden behind a wooden false ceiling, yet the central part openly shows the curved bar truss to let the sunlight enter the central courtyard. This case, and certainly the latest model school (viz. Athenaeum Serge Cruz, 1920) (Figure 5, right) which openly shows an industrial-looking Ardant bar truss, clearly are forerunners of a new economic situation where standardization and prefabrication would gain on aesthetics, and where more easily calculable and buildable setups would find their introduction in non-industrial buildings.

Figure 6 shows a date-related chart of the Ardant trusses' different components. The chart is conceived in a way that it can help the user to establish the period of construction of any Ardant truss. Combining the building techniques of the principal rafters, tangential arch, vertical posts, web members 
and connection plates of an Ardant truss on this chart provides an idea of the construction period. Considering the construction period of the school Mabille (grey area of Figure 6), one expects double L-shaped section irons for the principal rafters, tangential arch and vertical posts, double T-shaped section irons for the web members, and gusset plates or no plates at all for the connections. Photographs of a recent visual inspection confirm this setup (Figure 7).

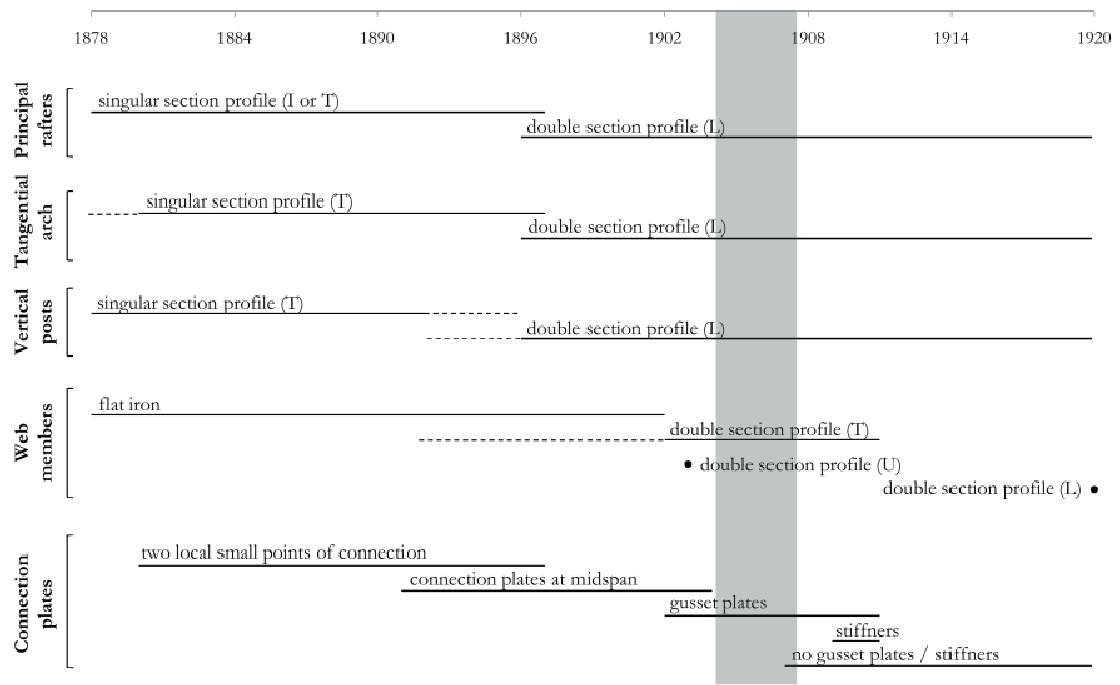

Figure 6: Decision chart with regard to the evolution of the Ardant trusses' components.
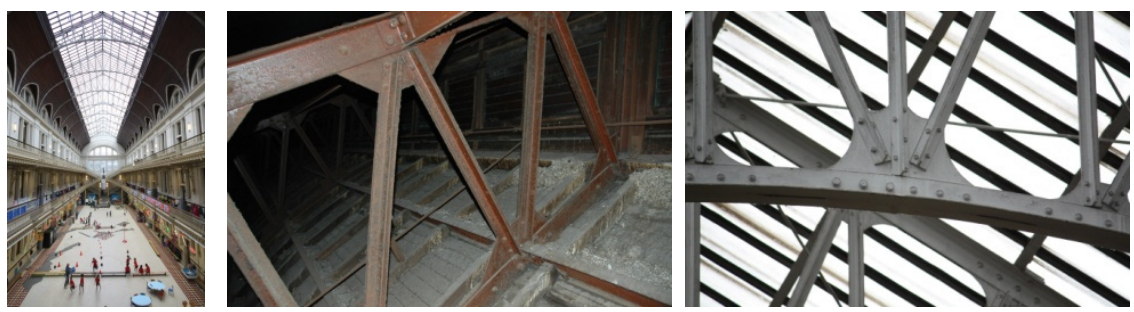

Figure 7: Details of the roof structure of the Brussels model school no.19 Alfred Mabille (1904-7).

Figure 8 indicates the location of the highest stresses and buckling ratios for six Ardant truss typologies, which were investigated in-depth during the author's PhD. This chart is an interesting tool when performing on-site surveys: it indicates the components and locations that definitely need special attention. The truss typology of the school Mabille is not (yet) included in the scheme, but it bears much resemblance with the grey indicated truss type. Within this truss type, structural issues with the lower part of the arch and with the flat iron web 
Location of the Ardant trusses' maximum stresses and stability problems

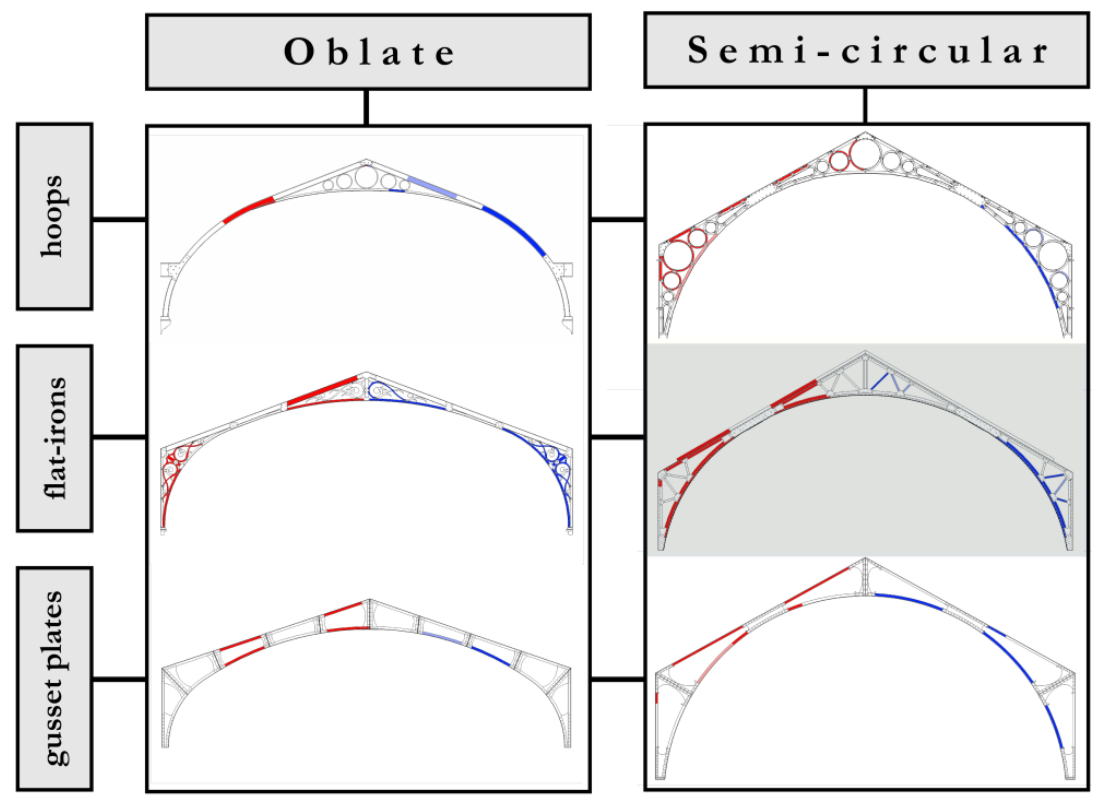

Figure 4: Localisation of the Ardant trusses' most critical components in function of the truss typology (red/left part of the trusses = location of the maximum stresses; blue/right part of the trusses = location of maximum stability ratios).

members are indicated. A visual inspection of the Mabille truss shows the use of bracings out of plane exactly at the indicated areas of the arch. Also the web members are adapted: they consist of double T-sections instead of flat-irons. So, at first sight, it seems that the Mabille truss - one of the latter Ardant trusses - is a refined evolution of the indicated truss typology which should have an improved structural behaviour (mainly out-of-plane). Further analysis of the truss - that is to say a 3D modelling and recalculation carried out within the course of renovation techniques by the students of the first master class at the Department of Architectural Engineering at the Vrije Universiteit Brussel in 2009-2010 - confirmed this finding: the abovementioned structural modifications improve the truss' structural behaviour in such a way that it meets all of the present-day requirements imposed by the Eurocodes. This also confirms the trend established in the author's PhD research, namely that the Ardant trusses at the time of the Brussels model schools were in full development and that their structural behaviour was continuously improving. 

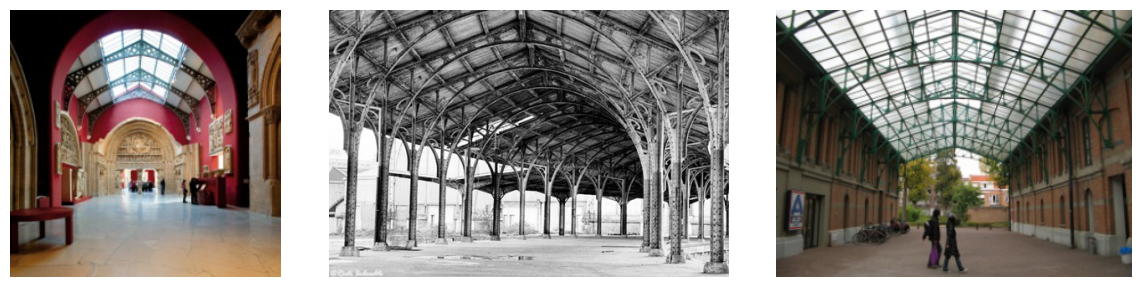

Figure 9: Cité de l'architecture et du patrimoine - Trocadèro (1878-9, Paris) (left) [20], fishing market of Tour \& Taxis (1905, Brussels) (middle) (by courtesy of Rudi Imbrechts), old city slaughterhouse of Leuven (1916-8, Leuven) (right).

To conclude, it must be mentioned that notwithstanding the research focused on the Ardant trusses of the Brussels model schools, these schemes form a basis that can be used for any kind of Ardant truss, even in other building types, setups (even as complete frame structures without massive buttressing walls) and locations such as the Cité de l'architecture et du patrimoine - Trocadèro (18789, Paris), the fishing market of Tour \& Taxis (1905, Brussels), the old city slaughterhouse of Leuven (1916-8, Leuven) (Figure 9), etc.

\section{Conclusions}

The metal roof trusses of the (semi-)public Brussels model schools, built between 1875 and 1920, sketch a good picture of the fascination and discord of the architects and engineers of that age to find an appropriate architectural language for the new building materials iron and steel. Prior to 1900 efficiency had an overriding importance and they recurred to the well-known and efficient but industrial-looking Polonceau truss. Yet, not willing to openly show industrial-looking iron structures in non-industrial buildings to a broad public, they continued their search and struggle for an appropriate architectural expression and aesthetic solution. At first, they tried to resolve this 'problem' by embellishing the Polonceau truss by means of decorative spandrels. Yet, after 1900 when the calculation methods were known and standardization took over, the Polonceau's aesthetical counterpart, viz. the Ardant truss, would take the lead within the model schools.

Three main phases can be established with regard to the Ardant trusses. In first instance, the oldest model schools' Ardant examples indeed seemed to provide a perfect substitute for the Polonceau truss: according to the historic definition of efficiency (weight-to-span ratio) both truss types were equally efficient, yet the Ardant truss was much more appropriate for ornamentation.

The second phase sets in at the turn of the century, when the weight-to-span ratio of the Ardant trusses all of a sudden increased strongly, indicating a loss of efficiency. And yet, from 1900 onwards most of the model schools opted for the Ardant truss. This can be explained by the facts that by that time more accurate calculation techniques arose, standardization set in, and labour costs became more important than material costs due to new iron and steel production 
techniques. Analysis according to the Eurocodes demonstrated that this change in conception and the consequential increase in use of material (and apparent cease of efficiency) were a good move. After all, the earliest Ardant examples showed important deficiencies according to the modern analyses, whereas the later examples performed quite well.

The third and final phase is characterised by the fact that - notwithstanding the Ardant truss originated from the idea to create a greatly aesthetic truss with a high decorative potential - standardisation, prefabrication and mass production took over: probably due to the ease of calculation, production and assemblage in the last model schools the once filigree, curved and decorative alternative to straight industrial bar roof trusses ceded to industrial-looking Ardant trusses with straight components.

Finally, in order to guide engineers, architects, historians, government officials, etc. in their preparatory assessment of Ardant trusses, the paper concludes by summarizing these main findings in three clear-cut decision schemes: one on the roofs' construction techniques, a second one which is a date-related chart of the Ardant trusses' components, and a last scheme indicating for six truss typologies the most important components and locations to be inspected.

\section{Acknowledgements}

The presented results were obtained during the author's $\mathrm{PhD}$ research, conducted at the department of Architectural Engineering at the Vrije Universiteit Brussel (Belgium) and funded by the Research Foundation - Flanders (FWO).

\section{References}

[1] S.C.A.B., "L’Émulation (9ième année)" 1884.

[2] Vierendeel, A., L'architecture métallique au XIXe siècle et l'exposition de 1889, à Paris, Librairie Scientifique, Industrielle et Agricole E. Ramlot: Bruxelles, 1890.

[3] Giedion, S., Building in France, building in iron, building in ferroconcrete. The Getty Centre for the History of Art and Humanities: Canada, 1995.

[4] S.C.A.B.: "L’Émulation (18ième année)" 1893.

[5] Combaz, P., La construction: principes et applications, E. Lyon-Claesen: Bruxelles, 1897.

[6] de Bouw, M., Brussels Model Schools - Structural Analysis of the Metal Roof Trusses, VUB Press: Brussels (doctoral thesis), 2010.

[7] Demey, T., Geschiedenis van de Brusselse scholen. Ministerie van het Brussels Hoofdstedelijk Gewest: Brussel, 2005.

[8] Reyns, R., De lagere school in België, van de middeleeuwen tot nu, ASLK - Galerij: Brussel, 1987. 
[9] de Bouw, M., Wouters, I., Lauriks, L., Forty Years of de Dion Trusses in Nineteenth Century Brussels Model Schools. Proc. of the $3^{\text {rd }}$ Int. Conf. on Construction History, Cottbus, pp. 437-444, 2009.

[10] Nieuwmeijer, G., Polonceau-spanten. Monumenten, 11, pp. 20-23, 2001.

[11] Schädlich, C., Der Baustoff Eisen als Grundlage für die Herausbildung qualitativ neuer Baukonstruktionen im 19. Jahrhundert. Zur Geschichte des Konstruierens, ed. R. Graefe, Stuttgart, pp. 138-151, 1989.

[12] Holzer, S., The Polonceau Roof and its Analysis. International Journal for the history of Engineering and Technology, 80 (1), pp. 22-54, 2010.

[13] Holzer, S., Vom Einfluss des Analysewerkzeugs auf die Modellbildung Zur statischen Analyse des Wiegmann-Polonceau-Trägers in der 2. Hälfte des 19. Jahrhunderts. Bautechnik, 83, pp. 428-434, 2006.

[14] Dechamps, H., Les principes de la construction de charpentes métalliques, Imprimerie H. Vaillant-Carmanne: Liège, 1888.

[15] Vierendeel, A., La construction architecturale en fonte, fer et acier, Bruxelles-Louvain-Paris, 1902.

[16] Steiner, F.H., French iron architecture, UMI Research Press: Michigan, 1984.

[17] Ardant, P., Etudes théoriques et expérimentales sur l'établissement des charpentes à grande portée, S. Lamort: Metz, 1840.

[18] Lemoine, B., L'architecture du fer - France: XIXe siècle. Champ Vallon: Seyssel, 1986.

[19] Holzer, S., Der Bogen im Dach - Zur Entwicklung des weitgespannten Daches 1770-1840 unter dem Einfluß des frühen Bauingenieurwesens. Bautechnik, 84, pp. 130-146, 2007.

[20] http://www.journeesdupatrimoine.culture.fr/, 16052011. 